\title{
Is an Inhibitor or Blocker of Inactivation of Glycogen Synthase Kinase- $3 \beta$ (GSK-3 $\beta)$ a Reliable Agent for Cancer Chemotherapy?
}

\section{Yoshimi Ichimaru, Hiroaki Saito and Shinichi Miyairi}

Laboratory of Organic Chemistry, School of Pharmacy, Nihon University, 7-7-1, Narashinodai, Funabashi, Chiba 274-8555, Japan

\begin{abstract}
Tyrosine kinase inhibitors such as imatinib $\left(\right.$ Glivec $\left.^{\circledR}\right)$ and sunitinib $\left(\right.$ Sutent $\left.^{\star}\right)$ are useful drugs in cancer chemotherapy and are called "molecular targeting agents" [1]. Kinase inhibition is thus considered a promising anti-cancer mechanism. Two categories of kinases are present in cells; one class called tyrosine (Tyr) kinases phosphorylates tyrosine residues in the target protein, and the other class called serine/threonine (Ser/Thr) kinases phosphorylates serine or threonine residues. Although the leading molecular targeting agents target Tyr kinases, a new drug called palbociclib (Ibrance ${ }^{\circ}$ ) targets cyclin-dependent kinase (CDK), which is a Ser/Thr kinase [2]. Glycogen synthase kinase-3 $\beta$ (GSK-3 $\beta$ ) is a proline-directed Ser/Thr kinase and a key enzyme in the cell cycle along with CDK. GSK-3 $\beta$ was originally identified as a key regulatory enzyme in the glycogen synthesis pathway, which inactivates glycogen synthase by phosphorylation [3]. Subsequently, several important physiological roles for GSK-3 $\beta$ have been identified in embryogenesis, neural differentiation, and cell division. In these processes, GSK- $3 \beta$ regulates the activities of transcription factors and cell signaling pathways such as Wnt/ $\beta$-catenin signaling and PI3K/Akt signaling. GSK-3 $\beta$ transfers a phosphate molecule onto $\beta$-catenin, NF- $\kappa B$, NFAT, Snail, c-Myc, p53, tau protein, and CRMP-2 in multiple physiological signaling pathways [4]. In the kinase cascade, GSK-3 $\beta$ is also a substrate of several kinases and the enzyme activity is regulated. Phosphorylation at Tyr-219 of GSK-3 $\beta$ by PyK2 and FYN up-regulates GSK-3 $\beta$ activity. In contrast, phosphorylation at Ser- 9 of GSK-3 $\beta$ by PI3K, Akt (PKB), and p90 $0^{\mathrm{RSK}}$ down-regulates GSK-3 $\beta$ activity [5]. Because the expression of these kinases is regulated by extracellular factors such as growth factors, hormones, and cytokines, GSK-3 $\beta$ activity is significantly influenced by the physiological state of the whole body. Accordingly, modulation of the enzymatic activity of GSK-3 $\beta$ is considered important in pharmacotherapeutics for diseases such as neurological disorders and cancer.
\end{abstract}

\section{Inhibitor of GSK-3 $\beta$}

Lithium ion $\left(\mathrm{Li}^{+}\right)$is the simplest GSK-3 $\beta$ inhibitor and blocks activity in a non-competitive manner by interacting with the substrate protein. Actually, $\mathrm{Li}^{+}$competes with magnesium ions $\left(\mathrm{Mg}^{2+}\right)$ at the ATP-binding site by direct binding. When the $\mathrm{Li}^{+}$ concentration is maintained near the Ki value of GSK-3 $\beta(2 \mathrm{mM})$, physiologically essential enzymes such as inositol monophosphatase (Ki: $0.8 \mathrm{mM}$ ), inositol polyphosphate 1-phosphatase $(0.3 \mathrm{mM})$, and fructose 1,6-bisphosphatase $(0.3-0.8 \mathrm{mM})$ are strongly inhibited [6]. Accordingly, a more specific inhibitor of GSK-3 $\beta$ with a much high affinity is needed. Because the structures of the ATP-binding site in Ser/Thr kinases are different from those in Tyr kinases, some adenine-like compounds may be candidates for specific and effective GSK-3 $\beta$ inhibitors (e.g., 6-bromoindirubin 3'-oxime: BIO). However, compounds such as BIO may also inhibit CDK [7]. As we described above, GSK-3 $\beta$ is involved in multiple signaling pathways, and the pharmacological action of an inhibitor is a combined result of its multifunctional properties. For example, BIO is a potent inhibitor of GSK-3 $\beta$ and has anti-proliferative activity on cancer cells. GSK$3 \beta$ down-regulates the cell cycle by suppressing cyclin $\mathrm{D}$ production after degradation of $\beta$-catenin, because the complex of cyclin D and

\author{
Publication History: \\ Received: February 09, 2016 \\ Accepted: February 15, 2016 \\ Published: February 17, 2016
}

\section{Keywords:}

\section{GSK-3 $\beta$, Indirubin, Celecoxib}

CDK4/ 6 drives G1 phase progression in the cell cycle. Because GSK$3 \beta$ catalyzes degradation of $\beta$-catenin by phosphorylation, inhibition of GSK-3 $\beta$ leads to promotion of the cell cycle. However, antiproliferative effects are due to inhibition of cell cycle progression. These contradictory data suggest that BIO inhibits CDKs as well as GSK-3 $\beta$ in anti-proliferative pathways. We determined the antiproliferative activity to evaluate the biological significance of newly developed indirubin derivatives as anti-cancer agents. We successfully developed an effective compound $\left(\mathrm{IC}_{50}: 1.7 \mu \mathrm{M}\right)$ with anti-proliferative activity that is comparable with that of cis-platin, a powerful anticancer agent [8].

From another viewpoint, GSK-3 $\beta$ down-regulates glycogen synthesis by phosphorylation of its synthase. When GSK-3 $\beta$ is inhibited over the long term, ATP production is suppressed due to depletion of free glucose after elevation of glycogen synthesis. This assumption suggests that one possible mechanism of the antiproliferative activity of GSK-3 $\beta$ inhibitors is deterioration of cell viability by starvation of cellular ATP.

\section{Blocker of the inactivation of GSK-3 $\beta$}

Celecoxib, a useful non-steroidal anti-inflammatory drug and a selective inhibitor of cyclooxygenase-2 (COX-2), shows antiproliferative activity on cancer cells due to suppression of progression through the $\mathrm{G} 1$ phase of the cell cycle. In this case, production of cyclin $\mathrm{D}$ is suppressed by depletion of $\beta$-catenin,the degradation of which is catalyzed by GSK-3 $\beta$ [9]. However, celecoxib promotes neither GSK-3 $\beta$ expression nor activation directly. As we described above, GSK-3 $\beta$ is down-regulated by phosphorylation at Ser-9 by several kinases including Akt and PI3K. Surprisingly, celecoxib inhibits Akt, and therefore, the inactivation of GSK-3 $\beta$ is suppressed. Because overexpression of cyclin $\mathrm{D}$ is observed in various types of cancer cells, up-regulation of GSK-3 $\beta$ may be valuable in cancer therapy.

"Corresponding Author: Dr. Shinichi Miyairi, Laboratory of Organic Chemistry, School of Pharmacy, Nihon University, 7-7-1, Narashinodai, Funabashi, Chiba 274-8555, Japan, Tel: +81-47-465-6290; Fax: +81-47-465-6353; E-mail: miyairi.shinichi@nihon-u.ac.jp

Citation: Ichimaru Y, Saito H, Miyairi S (2016) Is an Inhibitor or Blocker of Inactivation of Glycogen Synthase Kinase-3 $\beta$ (GSK-3 $\beta$ ) a Reliable Agent for Cancer Chemotherapy? Int J Clin Pharmacol Pharmacother 1: 102. doi: https:// doi.org/10.15344/2456-3501/2016/102

Copyright: (c) 2016 Ichimaru et al. This is an open-access article distributed under the terms of the Creative Commons Attribution License, which permits unrestricted use, distribution, and reproduction in any medium, provided the original author and source are credited. 
Citation: Ichimaru Y, Saito H, Miyairi S (2016) Is an Inhibitor or Blocker of Inactivation of Glycogen Synthase Kinase-3 $\beta$ (GSK-3 $\beta$ ) a Reliable Agent for Cancer Chemotherapy? Int J Clin Pharmacol Pharmacother 1: 102. doi: https://doi.org/10.15344/2456-3501/2016/102

Page 2 of 2

\section{Conclusion}

Recently, GSK-3 $\beta$ has been considered a target protein for the development of novel anti-cancer agents. GSK-3 $\beta$ is a kinase that is involved in various signaling pathways. Because GSK-3 $\beta$ plays a crucial role in cell proliferation, inhibition of cell cycle progression is expected to be a main mechanism of action of such anti-cancer agents. Cell cycle progression is a complicated process that is regulated by numerous factors such as cyclins and kinases including CDKs, PI3K, Akt, DDK, and ATR in combination or individually. Anti-proliferative activities have been found in both inhibitors and an inhibitor of activation of GSK-3 $\beta$. These contradictory observations suggest that small molecules interact with many intracellular components in addition to the biochemical effectors that have been characterized. Recently, celecoxib was reported to inhibit NF- $\mathrm{kB}$ (via $\mathrm{I}-\mathrm{\kappa B}$ degradation after COX-2 inhibition) as well as Akt [10]. This finding leads to the controversial result that celecoxib suppresses apoptosis via inhibition of NF- $\mathrm{kB}$ and directs cells toward death via inhibition of Akt. Accordingly, no clear direction exists regarding whether to choose up- or down-regulation of GSK-3 $\beta$ for developing novel anti-cancer agents. However, because GSK-3 $\beta$ is thought to be an incidental factor in Alzheimer's disease and type II diabetes, upregulation of the enzyme may enhance the risks of these diseases. On the other hand, BIO, which is a GSK- $3 \beta$ inhibitor, suppresses phosphorylation of amyloid precursor protein and tau and may be therapeutically useful in neurodegenerative disorders such as Alzheimer's disease, Parkinson's disease, and bipolar disorder. Furthermore, BIO has anti-hyperglycemic potential in addition to anti-inflammatory potential and promotion potential in osteogenesis $[11,12]$. Although the mechanism is unclear, GSK-3 $\beta$ inhibitors with anti-proliferative activity are anticipated for development of novel anti-cancer agents.

\section{Competing Interests}

The authors declare that they have no competing interests.

\section{References}

1. Montemurro M, Gelderblom H, Bitz U, Schütte J, Blay JY, et al. (2013) Sorafenib as third- or fourth-line treatment of advanced gastrointestinal stromal tumour and pretreatment including both imatinib and sunitinib, and nilotinib: A retrospective analysis. Eur J Cancer 49: 1027-1031.

2. Cadoo KA, Gucalp A, Traina TA (2014) Palbociclib: an evidence-based review of its potential in the treatment of breast cancer. Breast Cancer (Dove Med Press) 6: 123-133.

3. Embi N, Rylatt DB, Cohen P (1980) Glycogen synthase kinase-3 from rabbit skeletal muscle. Separation from cyclic-AMP-dependent protein kinase and phosphorylase kinase. Eur J Biochem 107: 519-527.

4. McCubrey JA, Steelman LS, Bertrand FE, Davis NM, Sokolosky M, et al (2014) GSK-3 as potential target for therapeutic intervention in cancer. Oncotarget 5: 2881-2911.

5. Sutherland C, Leighton IA, Cohen P (1993) Inactivation of glycogen synthase kinase-3 beta by phosphorylation: new kinase connections in insulin and growth-factor signalling. Biochem J 296 : 15-19.

6. Phiel CJ, Klein PS (2001) Molecular targets of lithium action. Annu Rev Pharmacol Toxicol 41: 789-813.

7. Meijer L, Skaltsounis AL, Magiatis P, Polychronopoulos P, Knockaert M, et al. (2003) GSK-3-selective inhibitors derived from Tyrian purple indirubins. Chem Biol 10: 1255-1266.
8. Ichimaru Y, Saito H, Uchiyama T, Metori K, Tabata K, et al. (2015) Indirubin 3'-(O-oxiran-2-ylmethyl)oxime: a novel anticancer agent. Bioorg Med Chem Lett 25: 1403-1406.

9. Yang HM, Kim HS, Park KW, You HJ, Jeon SI, et al. (2004) Celecoxib, a cyclooxygenase-2 inhibitor, reduces neointimal hyperplasia through inhibition of Akt signaling. Circulation 110: 301-308.

10. Funakoshi-Tago M, Shimizu T, Tago K, Nakamura M, Itoh H, et al. (2008) Celecoxib potently inhibits TNFalpha-induced nuclear translocation and activation of NF-kappaB. Biochem Pharmacol 76: 662-671.

11. Gunn WG, Krause U, Lee N, Gregory CA (2011) Pharmaceutical inhibition of glycogen synthase kinase- $3 \beta$ reduces multiple myeloma-induced bone disease in a novel murine plasmacytoma xenograft model. Blood 117: 1641-1651.

12. Huang WC, Lin YS, Wang CY, Tsai CC, Tseng HC, et al. (2009) Glycogen synthase kinase- 3 negatively regulates anti-inflammatory interleukin-10 for lipopolysaccharide-induced iNOS/NO biosynthesis and RANTES production in microglial cells. Immunology 128: e275-286. 